\title{
Unintended outcomes of farmers' adaptation to climate variability: deforestation and conservation in Calakmul and Maya biosphere reserves
}

\author{
Claudia Rodriguez-Solorzano, ${ }^{1,2}$
}

\begin{abstract}
Minimizing the impact of climate change on farmer livelihoods is crucial, but adaptation efforts may have unintended consequences for ecosystems, with potential impacts on farmers' welfare. Unintended outcomes of climate adaptation strategies have been widely discussed, however, empirical exploration has been neglected. Grounded in scholarship on climate adaptation, environmental governance, social-ecological systems, and land-use change, this paper studies whether farmers' climate adaptation contributes to deforestation or forest conservation. The paper draws on interviews with 353 farmers from 46 communities in Calakmul Biosphere Reserve in Mexico and Maya Biosphere Reserve in Guatemala. Farmers in the area of study have implemented adaptation strategies that people around the world have used for centuries, including migration, diversification, savings, and pooling. The findings show that climate adaptation can increase deforestation or support forest conservation depending on the type of adaptation strategy farmers implement. Saving, based on cattle ranching, is a deforestation-driving strategy. The choice of this strategy is influenced by distance to the commercial and administrative center and cash benefits from the forest. Deforestation can have a negative impact on farmers' welfare, as well as harm biodiversity and contribute to increased climate change. Thus, deforestation-driving adaptation strategies may be ineffective. However, diversification, based on off-farm jobs and operating provision shops, is a conservation-driving strategy influenced by distance as well as by family size. Farmers who choose diversification to adapt may contribute to a virtuous circle in which livelihood improvement in the short term leads to enhanced social-ecological resilience in the longer term. The need for farmers to implement adaptation strategies thus represents great risk but also opportunities.
\end{abstract}

Key Words: climate adaptation; governance; institutions; land-use change; Latin America; protected areas

\section{INTRODUCTION}

Climate change is affecting the livelihoods of millions of families in rural areas around the world. Farmers in frontier regions who rely on seasonal agriculture are facing serious economic losses and shorter recovery periods due to more intense and more frequent droughts, floods, or hurricanes, as well as higher unpredictability of rains (Bohle et al. 1994, Intergovernmental Panel on Climate Change (IPCC) 2007a). The development of adaptation strategies aiming to minimize the impact of climate change on farmers' livelihoods is thus crucial (Abramovitz et al. 2002). However, farmers' adaptation might also produce unintended outcomes (Batterbury and Forsyth 1999, Adger et al. 2005, Barnett and O’Neill 2010, Cinner et al. 2011, Fazey et al. 2011). For instance, if farmers' adaptation strategies contribute to deforestation, adaptation can become ineffective and inequitable. Alternatively, adaptation might contribute to forest conservation, supporting social and ecological resilience simultaneously. Hence, empirical studies of the effects of adaptation beyond its goal to support livelihoods in the face of climate stimuli are necessary, yet still scarce.

Adaptation as a field of study has already recognized the importance of adaptation effectiveness, maladaptation and ecosystem-based adaptation (Barnett and O'Neil 2010, Locatelli et al. 2010, Brown 2011, Eriksen and Brown 2011). These studies acknowledge the potential of adaptation to produce unintended outcomes, as well as the importance of implementing adaptation strategies that protect ecosystem services. Nevertheless, these studies are mostly conceptual and theoretical. The literature on adaptation has not yet provided empirical cases analyzing the secondary outcomes of farmers' climate adaptation on forests. Likewise, for decades scholars have extensively studied land-use change (Angelsen and Kaimowitz 2001, Rudel et al. 2009, Turner 2010b, Lambin and Meyfroidt 2011, Hosonuma et al. 2012), without analyzing the impact of adaptation as a deforestation driver.

Grounded in scholarship on climate adaptation, environmental governance, social-ecological systems, and land-use change (Agrawal 2001, Lambin et al. 2001, Adger 2005, Lemos and Agrawal 2006, Nelson et al. 2007, Ostrom 2009), in this paper, I study whether farmers' climate adaptation contributes to deforestation or forest conservation in two biosphere reserves in Mexico and Guatemala. Pursuing this question without accounting for demographic, economic, and institutional factors, already identified as key to explaining land-use change (Lambin et al. 2001, Rudel 2006, Bottazzi and Dao 2013), would however overestimate the contribution of adaptation strategies (Agrawal and Chhatre 2006). An additional concern to take into account for the analysis of the relationship between adaptation and forest cover change is related to the distinction between proximate and underlying causes of forest change (Geist and Lambin 2001, Turner et al. 2007). To address these concerns, I examine the influence of adaptation strategies, as proximate causes, together with socioeconomic and institutional factors, as underlying causes, on changes in deforestation/forest conservation.

\section{CALAKMUL AND MAYA BIOSPHERE RESERVES}

Calakmul Biosphere Reserve in Campeche, Mexico, and Maya Biosphere Reserve (MBR) in Petén, Guatemala, are internationally adjoining protected areas (Fig. 1). Both biosphere reserves are predominantly karstic lands, covered with seasonally dry tropical forest, tropical evergreen, semi-evergreen, deciduous, and semideciduous forests (Schwartz 1990, Klepeis and Turner 
2001, Pérez-Salicrup 2004, Pronatura Península de Yucatán (PPY) and The Nature Conservancy (TNC) 2006). Together, Calakmul and Maya Biosphere Reserve represent the second largest contiguous tropical forest in the Americas $\left(28,833 \mathrm{~km}^{2}\right)$; Calakmul covers $7,231 \mathrm{~km}^{2}$ and MBR extends over $21,602 \mathrm{~km}^{2}$ (Instituto Nacional de Ecologia (INE) 1999, Consejo Nacional de Àreas Protegidas (CONAP) 2001b). Together, these biosphere reserves protect an important conservation hotspot called Selva Maya (Bray et al. 2008, Conservation International (CI) 2012).

Fig. 1. Calakmul and Maya Biosphere Reserves

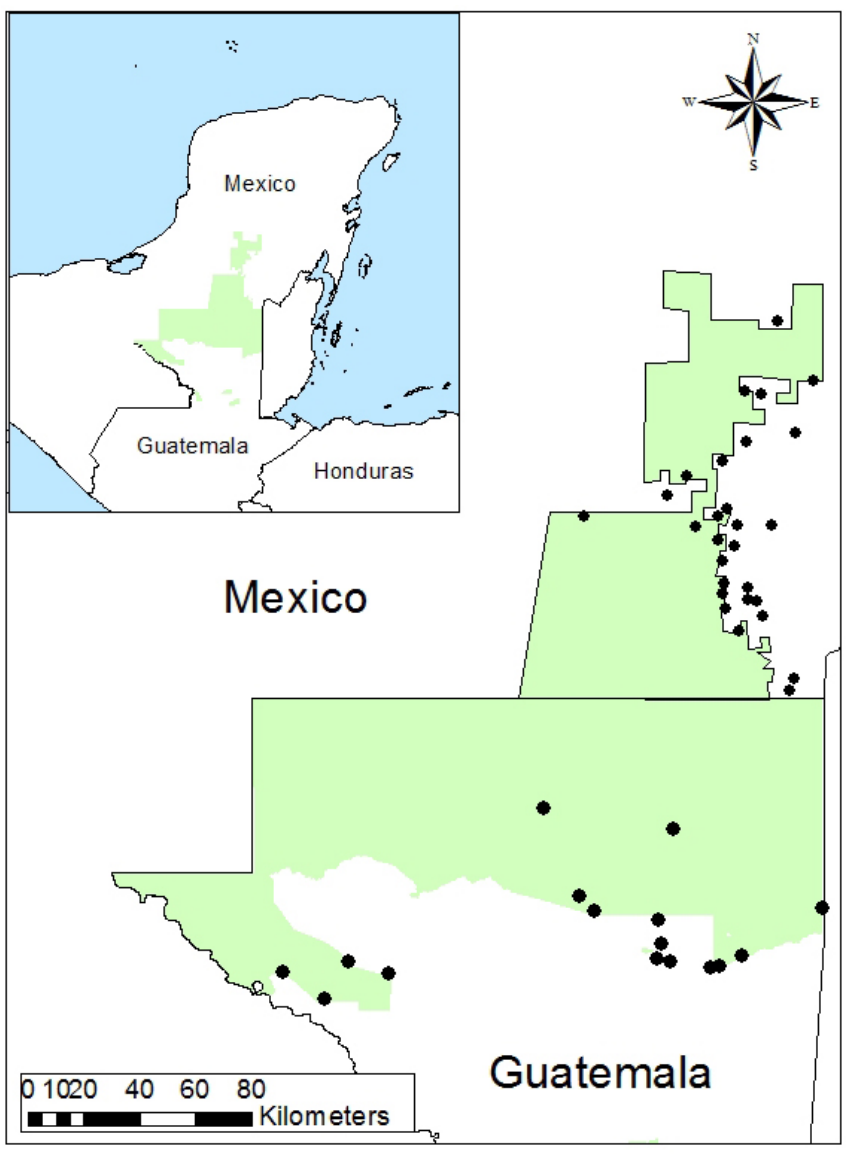

The region covered by the studied biosphere reserves was heavily used during the times of the great Maya civilization (Klepeis and Turner 2001). After the ancient Maya cities were abandoned, around 900 A.D., the forest grew back and the area remained scantily populated. With few people in the region, the forest that grew over Maya ruins was used only for timber and nontimber forest products extraction (Primack et al. 1997, Turner et al. 2004). The old-growth forest started to decline dramatically in the $1960 \mathrm{~s}$ when indigenous and nonindigenous farmers from different regions in Mexico and Guatemala moved to the region in search of land (Schwartz 1987, Carr 2000, Arreola et al. 2004, Milian 2008). In MBR, land speculators and ranchers have also had a critical influence on the forest conditions (Schwartz 1990). Following the relatively recent settlements, Calakmul and Maya Biosphere Reserves were established in 1989 and 1990 (Acopa and Boege 1997, Ponciano 1997).
The population of both biosphere reserves is diverse, including indigenous communities. In Calakmul Biosphere Reserve, 24.4\% of the population is indigenous. The Maya Yucatec represent $8.5 \%$ of the indigenous population. The remaining $91.5 \%$ of the indigenous people are not originally from Calakmul, but from Chiapas, including Cho'ol, Tzeltal, and Tsotsil (Calakmul 2012). In MBR, by $2009,32.1 \%$ of the population was indigenous. The Mayeros or indigenous people from Petén represented only $0.9 \%$ of the indigenous population. The remaining indigenous people were not from Petén, but came from different regions in Guatemala and included Q'eqchi and other Maya groups (Grandia 2009, Ybarra et al. 2012). Among the small percentage of indigenous people in the region, only the Maya Yucatec and Mayeros have traditional knowledge specific to Calakmul and Maya Biosphere Reserves. The indigenous people that came from different regions within Mexico and Guatemala and who have made Calakmul and Maya Biosphere Reserves their home are likely to have rich traditional knowledge, but specific to the regions where they came from, which have different ecological characteristics (field research interviews). The background of the nonindigenous population in Calakmul and MBR is diverse; they come from multiple regions in both countries (Calakmul 2012, Ybarra et al. 2012). Despite their ethnic and geographical background differences, both indigenous and nonindigenous people share an interest in working the land.

Different sources contribute to the economy of these biosphere reserves; however, most households rely on agriculture (Turner et al. 2004, Roy Chowdhury 2010). The main crop is corn, although there are also cash crops, such as chili and squash (CONAP 2001a, Schmook et al. 2003, Keys and Roy Chowdhury 2006, Calakmul 2009, Ybarra et al. 2012). Cattle have become more prominent more recently, despite price and water availability challenges (Grandia 2009, Busch and Geoghegan 2010, Turner 2010a). Forestry and tourism have also increased their importance over the years, but more so in MBR than in Calakmul. Tikal and the forest concessions in Petén have produced more revenues than the archeological site of Calakmul and the forest concessions in southern Campeche (Gómez and Méndez 2007, Radachowsky et al. 2012).

Water is a critical issue in this drought-prone region (Scarborough and Gallopin 1991, Turner et al. 2004). Calakmul's geological conditions prevent the formation of surface lakes or rivers (Faust et al. 2004). In MBR, there are some superficial water bodies, including Lake Petén-Itza and Yaxha lagoon in the central area, and the Rio Usumacinta in the west. Nevertheless, farmers in neither Calakmul nor MBR have access to irrigation, which, together with the regional strong reliance on agriculture, makes them vulnerable to the more severe climate variability of recent years.

\section{CLIMATE AND ADAPTATION}

During the interviews, farmers from both biosphere reserves revealed that they had implemented adaptation strategies to minimize the negative effects that climate had over their livelihoods in a period of 5 to 10 years. Ninety-four percent of the interviewed farmers claimed "el clima ha cambiado" (climate has changed). Farmers were not referring to global climate change, but to precipitation patterns that differed from what they were accustomed to. Some farmers, mostly from Calakmul, 
explained to me that for three decades, since the mid 1960s, when the current settlements were created, the seasonal rains consistently started on May 1st. In the late 1990s, they started to notice that rains became very erratic. This is, they observed that the beginning of the rain season was no longer May 1st. Some years, the seasonal rains would start in early May, some years in mid May, and in the worst years, in June, after having had some isolated rainy days in May.

The lack of consistency from one year to the next and especially the isolated rainy days in May made it difficult for farmers to figure out a new rain pattern to define their planting calendar. This change in precipitation patterns has been also observed by farmers in northern Yucatán (Faust 2004). Another subset of farmers, mainly from MBR, told me "things were not as good as they used to be." They had observed rains were below the historical average. Those farmers correlated the "change" in precipitation to local deforestation, which they believe changed their microclimate. Overall, in both biosphere reserves, farmers linked their agricultural losses, to which they are adapting, to the variation in precipitation they observe.

Climate data from the Mexican (Mexican National Water Commission (CNA) 2008) and Guatemalan (Instituto Nacional de Sismología, Vulcanología, Meteorología e Hidrología (INSIVUMEH) 2008) governments for two meteorological stations in Calakmul and one in MBR reveal that average, minimum and maximum precipitation in May have, in general, been greater in MBR than in Calakmul for the periods between 1978-1987 (Calakmul: avg. $81 \mathrm{~mm}$, min. $25 \mathrm{~mm}$, max. $187 \mathrm{~mm}$; MBR: avg. $156 \mathrm{~mm}$, min. $0.3 \mathrm{~mm}$, max. $223.4 \mathrm{~mm}), 1988-1997$ (Calakmul: avg. 49 mm, min. $19.3 \mathrm{~mm}$, max. $91.3 \mathrm{~mm}$; MBR: avg. $79 \mathrm{~mm}$, min. $28 \mathrm{~mm}$, max. $195 \mathrm{~mm}$ ), and 1998-2007 (Calakmul: avg. $106 \mathrm{~mm}$, min. $48 \mathrm{~mm}$, max. $206.5 \mathrm{~mm}$; Maya: avg. $139 \mathrm{~mm}$, min. $45 \mathrm{~mm}$, max. $287 \mathrm{~mm}$ ). According to the limited meteorological data available, which miss information for some years and include only three stations for the whole area of study, precipitation in May has been variable in both biosphere reserves over time, not only in the last 5 to 10 years. However, the range within which rain levels have varied from year to year has expanded over the last decade in both biosphere reserves, having more pronounced variability in MBR than in Calakmul. Since the meteorological data available do not report the number of days with precipitation in May, it is not possible to know if farmers received most or all of the rain the meteorological services reported for May within 1 or 2 weeks at the end of the month and struggled for 2 or 3 weeks in early May.

Meteorological data as well as farmers' testimonies indicate that, due to climatic conditions, families in Calakmul and MBR have gone through very difficult periods in the past, not only in the years that preceded this research (Schmook et al. 2013). Yet, the intensity of the losses reflected in lower corn yields derived from climate variability has been large enough to incentivize farmers to implement adaptation strategies. Farmers in Calakmul and MBR have implemented adaptation strategies that farmers around the world have used for centuries, including migration, diversification, savings, and pooling. These strategies have been adopted by rural societies to respond to climate stimuli, as well as to other stressors affecting farmers' livelihoods, such as political, economic, or social changes (Halstead and O'Shea 1989,
Eakin 2005, Agrawal 2008). The long and wide use of these adaptation strategies is linked to their potential to enable farmers to distribute risks across multiple dimensions. Through migration, farmers allocate risks over their livelihoods in different locations. Savings help to spread risks over time; people save what they make in good years to cover the shortages of bad years. Diversification of income sources allows farmers to distribute climate risks over different economic activities. Pooling allows farmers to share risks with a group of people who work together in a given enterprise.

\section{METHODS}

\section{Data Collection}

I conducted field research from August 2007 to March 2008 in Calakmul and from January to August 2009 in MBR. The data collection included interviews that I personally conducted with 353 households. The interviewees were always the head of the household. When the man had migrated, I interviewed his wife or children, whoever remained in charge of the family. All of the interviews were in Spanish, the language in which interviewer and interviewees were fluent, including people with indigenous background. The response rate was $99 \%$, only one interviewee in Calakmul and one in MBR refused to participate in the interviews. All of the interviewees were farmers from 46 communities, 30 from Calakmul and 16 from MBR. These communities represent $37 \%$ and $14 \%$ of the communities established in Calakmul and Maya Biosphere Reserves. Figure 1 shows the approximate location of these communities.

Communities and farmers were randomly selected. Both biosphere reserves maintain lists of communities inside the reserve and buffer zone. A random sample was generated using these lists. In each community, I interviewed the local authorities, comisario ejidal and cominsario municipal in Calakmul and alcalde auxiliar in MBR. Additionally, I interviewed key informants in each community, such as informal community leaders. The rest of the interviewees were randomly selected using the list of households maintained by the community governments. All of the interviewees were contacted and interviewed in their homes.

The sample of 353 farmers includes 287 landowners and 66 landless. Landowner refers to people holding a land property title, as well as de facto landowners. In Calakmul, landowners have a title or legal recognition of their rights. In MBR, some farmers have title, but an unknown number of them are de facto landowners having no legal registry supporting their ownership. Community members tend to treat de facto landowners as if they were de jure landowners, as they exercise access, extraction, management, alienation, and exclusion rights (Schlager and Ostrom 1992) over their plot in the same manner title landowners do. This is the case because none of the communities included in the research is an illegal settlement or faces the risk of eviction because of the biosphere reserve. Unwritten community rules also encourage community members and outsiders to respect de facto landowners' rights claims.

Additionally, I interviewed 53 officials representing nongovernmental organizations (NGOs), donors, federal, state, and municipal-level government, as well as members of decision-making councils at the community, regional, municipal, or biosphere reserve level. 
The interviews with these officials, 63 landless farmers, and my observations of decision-making councils helped me to understand the governance and institutions at the community and biosphere reserve level and supported qualitative analysis. The landless farmers could not be included in the quantitative analysis of changes in land cover because those farmers do not have a plot over which deforestation could be recorded.

\section{Adaptation Strategies and Changes in Forest}

In this paper, I call adaptation strategies contributing to deforestation deforestation-driving strategies. These strategies are likely to be ineffective in the long term because, by reducing immediate impacts of climate on farmers' livelihoods through means that increase forest loss, they also affect farmers' livelihood and welfare prospects. Deforestation can backfire on farmers because it has many implications, such as changes in the availability of forest goods and wildlife supporting farmers diets (Rao et al. 2010, Sunderland et al. 2013), or the erosion of ecosystems' capacity to provide ecosystem services supporting farmers' productivity, e.g., control of local hydrological cycles and soil conservation (Foley et al. 2005, Alcantara-Ayala and Dykes 2010). Additionally, deforestation can affect farmers' wealth and lives when linked to habitat loss and increased human-wildlife conflict (Woodroffe et al. 2005). Adaptation strategies contributing to deforestation would also have a reinforcing effect on climate change through increased $\mathrm{CO}_{2}$ emissions (Dale 1997).

Alternatively, climate adaptation strategies resulting in lower rates of deforestation, which I call conservation-driving adaptation strategies, can support social-ecological resilience. Conservationdriving adaptation strategies minimize the effects of climate variability on farmers' livelihoods while also maintaining habitats, the availability of forest products, and forests' capacity to produce ecosystem services. These strategies also contribute to emissions reduction and, in the tropics, they support biodiversity, which is associated with ecosystem resilience (Chapin et al. 2000).

Deforestation and forest conservation were measured by the number of hectares cleared within the plot owned by each farmer. If the relationship between adaptation strategies and the number of hectares cleared is statistically significant, the sign of the coefficient for that adaptation strategy would indicate if it is a deforestation-driving or conservation-driving strategy. During the interviews, farmers reported the size of their plots and the number of hectares they have under different types of land cover, e.g., old-growth forest, crops, pastures. The size of the plots is defined in farmers' land titles or in the community agreements of land distribution or are self defined, but recognized by other community members (field notes). The difference between the total size of the plot and the remaining old-growth forest in the plot indicated the number of hectares each farmer had cleared by the time of the interview. For instance, for a given household, forest cover change would be equal to 30 ha if the household owns a plot with 40 ha and has 10 ha of old-growth forest left. This measurement provides the number of hectares of old-growth forest farmers have cleared since they settled in the community. In order to normalize the distribution of the dependent variable, I used the square root of the number of hectares cleared in the HLM model used for the statistical analysis supporting this paper.

In Calakmul, the interviewees received their plot fully covered with old-growth forest and all of the forest clearance could be credited to the farmers owning each plot. In MBR, not every farmer interviewed acquired his plot fully covered with oldgrowth forest. In those cases, farmers estimated the number of hectares they had cleared since they got their plot. Fires could have affected the forest cover in some plots in both biosphere reserves. Farmers reported their forest losses due to fires and the amount of hectares cleared was adjusted in those cases to what farmers reported they had cleared.

Given that interviewees did not assess the quality of the forest, but the number of hectares they had cleared, the likelihood of subjectivity is removed. Farmers could have incentives to provide inaccurate information given the restrictions imposed by the protected areas on forest clearance. Nonetheless, interviewees showed strong willingness to speak about their land uses, their antagonism or support toward forest conservation policies, and to account for the number of hectares they have allocated for different uses. No interviewee hesitated or refused to provide landuse and deforestation information, and $99 \%$ of those who were asked to participate accepted. It was not possible to triangulate the interviewee's responses because, according to my interviews with officials at the Land Reform Ministry in Mexico and the Geographical Information System (GIS) office at the National Commission for Protected Areas in Guatemala, no official records or GIS data of land ownership and forest coverage at the farmer level exist.

\section{Adaptation Strategies-Proximate Causes}

Four adaptation strategies, widely used over history by rural societies (Halstead and O-Shea 1989, Eakin 2005) and also commonly used in Calakmul and MBR, were examined: (1) migration (Adger et al. 2002), (2) saving (van de Giesen et al. 2010), (3) diversification (Soini 2005), and (4) pooling (Agrawal and Perrin 2008). Farmers can pursue all of these strategies for multiple reasons, in addition to or instead of adaptation. Hence, I coded migration, saving, diversification, and pooling as adaptation strategies followed by farmers only when the interviewees explicitly said they (the head or any member of the household) were taking these actions, in part or fully, to minimize climate variability impacts in the last 5 to 10 years on their livelihoods. These are not mutually exclusive strategies; farmers can implement more than one adaptation strategy at the same time. However, the adoption of one strategy is independent from the adoption of another strategy. Adaptation strategies are independent dichotomous variables, denoting households' use or nonuse of them.

In Calakmul and MBR, these four strategies take specific forms related to the socioeconomic and institutional frameworks within which the interviewed farmers make decisions. Migration can be temporary or permanent, domestic or international, by one or several household members, by the head of the household or by any of its members. Migration is not a strategy exclusively or mostly used by particular groups of farmers. When farmers migrate, they allocate family labor to locations where climatic risks are uncorrelated. Savings in cash are rare in rural areas like Calakmul and MBR due to the absence of financial services. Storing food is a common alternative used to save in rural societies, but not an optimal saving strategy in the area of study because of the difficulty of keeping the food in good condition. Alternatively, cattle ranching allows farmers to save their 
Table 1. Variables description and summary Statistics

\begin{tabular}{|c|c|c|}
\hline Variable $^{\dagger}$ & Measurement & Range (Mean, SD) \\
\hline \multicolumn{3}{|l|}{ Dependent variable } \\
\hline Forest change (f) & Number of hectares cleared & $1-120(24,4.4)$ \\
\hline \multicolumn{3}{|l|}{ Proximate causes } \\
\hline \multicolumn{3}{|l|}{ Adaptation } \\
\hline Migration (f) & 1 household uses migration to adapt & $0-1(0.4,0.5)$ \\
\hline Saving (cattle) (f) & 1 household uses cattle to adapt & $0-1(0.2,0.4)$ \\
\hline Diversification (job) (f) & 1 household works off-farm to adapt & $0-1(0.2,0.4)$ \\
\hline Diversification (shop) (f) & $\begin{array}{l}1 \text { household operates a provision shop to } \\
\text { adapt }\end{array}$ & $0-1(0.1,0.3)$ \\
\hline Pooling (f) & $\begin{array}{l}1 \text { household pools resources with a group to } \\
\text { adapt }\end{array}$ & $0-1(0.2,0.4)$ \\
\hline \multicolumn{3}{|l|}{ Underlying causes } \\
\hline \multicolumn{3}{|c|}{ Socioeconomic and institutional factors } \\
\hline Population (f) & Number of household members & $1-33(5.4,3.2)$ \\
\hline Distance (com) & $\begin{array}{l}\text { Minutes from the community to the } \\
\text { administrative and commercial center by car }\end{array}$ & $5-210(51.6,45.6)$ \\
\hline Cash benefits from forest (f) & $\begin{array}{l}\text { Farmers perceive the cash benefits they } \\
\text { derive from the forest are } 0 \text { none to } 5 \text { very } \\
\text { high }\end{array}$ & $0-5(1,2)$ \\
\hline Exclusion (f) & $\begin{array}{l}1 \text { if farmers demanded government } \\
\text { compensation in exchange of forest } \\
\text { conservation }\end{array}$ & $0-1(0.3,0.4)$ \\
\hline
\end{tabular}

$\uparrow$ f - farmer-level variable; com - community-level variable; $\mathrm{N}=283$ for all variables, except for population $\mathrm{N}=262 ; \mathrm{SD}=$ standard deviation

surpluses from good years to cover the needs of bad years without losing liquidity, in addition to providing returns (offspring), and boosting their prestige and access to informal credit markets.

Diversification of income sources can take as many forms as farmers have interests, skills, or opportunities. Off-farm jobs as well as participating in the exchange of goods through local provision shops are two of the many income diversification strategies used in Calakmul and MBR. Pooling is supported by governmental and nongovernmental funds that promote the development of productive groups engaged in environmentally friendly or at least low land intensity economic activities.

\section{Socioeconomic and Institutional Factors-Underlying Causes}

To analyze whether adaptation strategies influence forest change while taking into account the theoretical insights the scholarship already offers about forest change, I examined four additional independent variables: (1) population, (2) distance, (3) cash benefits from the forest, and (4) participation in decision making. Population measures the number of household members and distance in minutes from the community to the commercial and administrative center by car. The variable cash benefits reflect farmers' perceptions about the cash benefits they receive from the forest. Farmers can derive cash benefits from multiple sources, including forest products sales and compensation for forest conservation. Participation was measured as exclusion from decision making at the protected area level. The interviews revealed that all of the farmers who felt the government does not take them into account in making decisions about natural resources in the region where they live and work also felt entitled to receive some compensation to comply with forest conservation regulations. Farmers who expressed that the government must compensate them for the conservation of the forest were then coded as farmers excluded from decision making. Table 1 presents the list of analyzed variables, the level at which they were measured -farmer (f) or community level (com), and measurement and descriptive statistics.

\section{Analysis}

I use a hierarchical linear model (HLM) (Raudenbush and Bryk 2002) to answer the research question using data of farmers nested within communities. The analysis of multilevel data generates results with larger generalization power than the analysis of single-level data, such as comparisons of communities without information on individual farmers or single community case studies that do not represent the wider context of the biosphere reserves. However, nested data require analytical tools, such as HLM models, that produce unbiased tests of the effects of the model because the assumption of independence of observations is violated, given that farmers within communities share characteristics (Gelman and Hill 2007, West et al. 2007). Hierarchical linear models are powerful for analyzing nested data, but they cannot directly model complex causal processes, such as those involved in the relationship between underlying and proximate causes (Bauer 2003).

In order to address this challenge I followed a mixed strategy consisting of analyzing the mediating influence of adaptation strategies using two HLM models and explaining the results in the light of the indepth knowledge I acquired during a year and 
Table 2. Model results

\begin{tabular}{|c|c|c|}
\hline Variable & $\begin{array}{l}\text { Full Model } \\
\text { Coeff. (St.Err) P }\end{array}$ & $\begin{array}{l}\text { Underlying Causes Model } \\
\text { Coeff. (St.Err) P }\end{array}$ \\
\hline \multicolumn{3}{|l|}{ Proximate causes } \\
\hline \multicolumn{3}{|l|}{ Adaptation } \\
\hline Migration (f) & $0.042(0.20)$ & \\
\hline Saving (cattle) (f) & $1.666(0.23) * * *$ & \\
\hline Diversification (job) (f) & $-0.666(0.25) * * *$ & \\
\hline Diversification (shop) (f) & $-0.801(0.26) * * *$ & \\
\hline Pooling (f) & $0.046(0.31)$ & \\
\hline \multicolumn{3}{|l|}{ Underlying causes } \\
\hline \multicolumn{3}{|c|}{ Socioeconomic \& institutional factors } \\
\hline Population (f) & $0.103(0.029) * * *$ & $0.126(0.032) * * *$ \\
\hline Distance (com) & $-0.010(0.003) * * *$ & $-0.011(0.003) * * *$ \\
\hline Cash benefits from forest (f) & $-0.172(0.074) * *$ & $-0.178(0.082) * *$ \\
\hline Exclusion (f) & $0.735(0.225) * * *$ & $0.891(0.245) * * *$ \\
\hline Intercept & $4.771(0.341) * * *$ & $4.800(0.347) * * *$ \\
\hline Number of farmers & 262 & 262 \\
\hline Number of com & 46 & 46 \\
\hline Prob $>$ chi $^{2}$ & 0.000 & 0.000 \\
\hline Prob $>=$ chibar $^{2}$ & 0.000 & 0.000 \\
\hline
\end{tabular}

a half of field research. Integrating quantitative and qualitative research is an important strategy for research on humanenvironment interactions (Agrawal and Chhatre 2011). The first HLM model, called the Underlying Causes Model, analyzes the influence of socioeconomic and institutional factors, already defined in the literature as underlying causes (Agrawal and Yadama 1997, Geist and Lambin 2002), on the number of hectares cleared by farmers. The second HLM model, called the Full Model, adds the adaptation strategies to the first model. If the socioeconomic and institutional factors' regression coefficients in the Full Model are smaller than the regression coefficients of these factors in the Underlying Causes model, then the statistically significant adaptation strategies are mediating the influence of the underlying causes. When adaptation strategies mediate the influence of socioeconomic and institutional factors, they carry all or part of the influence of the underlying causes and we can suggest they work as proximate causes (MacKinnon et al. 2000, Bauer et al. 2006). This analytical strategy is limited compared with structural equation modeling to explain complex causality. Yet, it offers insights of the indirect and direct drivers of deforestation and forest conservation in a multilevel context.

The statistical analysis only included the data provided by the 287 landowners. The information provided by the 66 landless farmers was important for understanding institutions and governance in the communities and biosphere reserves but could not be used in the quantitative analysis because landless farmers do not own a plot where the number of hectares they have cleared could be measured. The land that landless farmers use is either rented or borrowed from relatives or neighbors who clear old-growth forests and leave others to use secondary forest, in which soils are not as good. The total number of farmers analyzed in the HLM model is 262 because of missing data for some of the analyzed variables for 25 of them.

\section{RESULTS}

Table 2 provides information on the regression coefficients, standard errors, and statistical significance of the variables analyzed in the Full Model and the Underlying Causes Model. In both models, the residuals are normally distributed and no outliers or heteroscedasticity were found. The $\mathrm{chi}^{2}=0.0000$ (based on Wald Chi-square) rejects the null hypothesis that all of the coefficients in the models are equal to 0 . The Chibar ${ }^{2}=0.000$ suggests that the average number of hectares cleared varies between communities. Twenty-seven percent of that variance is explained in the Full Model by distance to the commercial and administrative center, the only community-level variable analyzed. The Underlying Causes Model is used only to check for mediation; hence it is not relevant for measuring the contribution of community-level variables to explain the variance in the average number of hectares cleared between communities. Due to the size of the sample, it is not possible to estimate if the influence of household-level variables on the number of hectares farmers clear varies depending on the community where the farmer lives.

The Full Model answers the question of whether adaptation strategies contribute to deforestation or forest conservation by indicating that there is not a common outcome for all adaptation strategies. Farmers' climate adaptation strategies can contribute to deforestation, forest conservation, or have no effect on the number of hectares farmers clear as well. Saving using cattle ranching is a deforestation-driving strategy. However, diversification through off-farm jobs or provision shops is a conservation-driving strategy. Migration and pooling are not statistically significant variables, which could be interpreted as if they were neutral strategies. This model also shows that the socioeconomic and institutional variables studied in this paper were statistically significant, as the theory predicted. A larger 
number of household members and exclusion of farmers from natural resources management decisions contribute to deforestation. Farmers' perception of a higher level of cash benefits from the forest and longer distances from farms to markets support forest conservation by decreasing the number of hectares farmers clear.

The comparison between the two models presented in Table 2 indicates that the regression coefficients of socioeconomic and institutional factors decreased with the introduction of diversification and saving adaptation strategies in the analysis. This change in coefficient values indicates these two statistically significant adaptation strategies explain part of the relationship between population, distance, cash benefits, and exclusion and the number of hectares farmers clear. This means that diversification and saving adaptation strategies are in the causal path between independent and dependent variables, which has two implications. First, the underlying causes influence farmers to choose cattle, jobs, and shops to adapt. Second, these three strategies work as direct causes of changes in the size of forest.

The evidence from Calakmul and MBR suggests that the strategies farmers follow to adapt to climate variability contribute to deforestation as well as to forest conservation. Thus, due to its negative and positive unintended outcomes, farmers' adaptation to current and future climate variability and change should be taken seriously. Yet, farmers' adaptation strategies are merely proximate causes of changes in the size of forests. Farmers' selection of a deforestation-driving adaptation strategy over a conservation-driving adaptation strategy depends on socioeconomic and institutional factors providing the context within which farmers make decisions. Farmers' context and adaptation strategies need to be analyzed simultaneously to gain a more complex understanding of the drivers of forest change and to tease out the direct and indirect drivers of deforestation and forest conservation.

\section{DISCUSSION}

Considering that the warming of the climate system is unequivocal (IPCC 2007b), the need to implement adaptation strategies to support farmers affected by climate is pressing. Yet, the strong and urgent call to implement climate adaptation strategies should not be an excuse to define adaptation goals and assess its success following a single dimension focused on livelihoods. It is important to learn from the development experience, in which large and irreversible processes of ecosystem degradation have occurred in the name of social needs.

The findings from this research suggest that the fate of the forest in an important conservation hot spot in the Americas is directly influenced by farmers' adaptation strategies. The implications of deforestation in this area are global due to biodiversity loss and $\mathrm{CO}_{2}$ emissions. At the local level, farmers expressed concerns during the interviews about the negative impacts deforestation has already had on their livelihoods. People are struggling with the reduced availability of firewood, wood for home construction, and game to add protein to their diets. Farmers also associate an increased rate of human and crop diseases with deforestation. They miss the shade and the recreation value of the forest that has been lost with deforestation. Some of them correlate local changes in precipitation patterns to deforestation.

\section{Distance, Cash Benefits, and Deforestation-Driving Adaptation Strategies}

Cattle ranching is a deforestation-driving strategy because it is a land-intensive activity. Cattle rarely substitute for agriculture. In general, farmers adopt cattle as a complementary income (Roy Chowdhury 2010). Farmers told me they choose cattle ranching as an adaptation strategy because it is the best option they have available to save. As mentioned in the results section, cattle ownership is influenced by socioeconomic and institutional factors. For instance, access to social status, liquidity, and informal credit markets also influence farmers to invest on cattle in the area of study and worldwide (Brondizio and Moran 2008, Herrero et al. 2009, Barona et al. 2010). My interviews with farmers also revealed that, in both biosphere reserves, distance to markets and cash benefits provide resources, affect opportunity and production costs, or define incentives that influence farmers' decisions to use cattle to adapt.

Distance to the commercial and administrative center is a key factor influencing the choice of cattle in Calakmul and MBR. Families living in more centrally located communities have comparative advantages vis-à-vis families living in distant communities for raising cattle. Proximity to the center increases farmers' access to veterinary care, inputs, technicians, and government officials supporting cattle ranching, in addition to reducing the cost of commercialization. Cattle ranching is inaccessible to those who cannot bear the cost of traveling to the center to get information and government subsidies to raise cattle or who can only receive a little pay for their cows from the middlemen who commercialize the animals and take a cut to compensate for transportation costs. Some farmers in remote communities told me that payment sometimes does not even cover the cost of raising the animals. Cattle ranching is a very complex social process in the region, involving land speculation, money laundering, and historical processes of social exclusion (Busch and Geoghegan 2010, Grandia 2012). Nonetheless, the use of it to save to adapt to climate variability has also contributed to the extension of cattle in the region and to the social costs of deforestation on farmers.

Cash benefits from the forest have a negative effect on cattle ranching by discouraging farmers from investing in it. When farmers receive cash from the forest, either through conservation programs or from selling forest products, the opportunity cost of clearing the forest increases and the incentives to raise cattle decrease. Benefits from the forest have been an important factor supporting conservation in different regions around the world (Gibson et al. 2000, Agrawal 2005, Persha et al. 2010). In Calakmul and MBR, people who are involved in commercialization of timber and nontimber forest products have become strong advocates of forest conservation. The forest concessions in MBR have had mixed experiences, but overall they constitute a success story for forest conservation based on the generation of cash benefits for farmers (Gómez and Méndez 2007, Bray et al. 2008, United Nations Development Programme (UNDP) 2012). Farmers who are not members of the forest concessions often expressed to me their wish to have the safety net that the concessions offer to their members and claimed their opportunities to conserve the forest are limited compared with those that members have. 
In Calakmul, groups of people working on tourism, traditional medicine, and honey production are examples of the great importance that the generation of benefits has to provide incentives for conservation. Beekeepers, in particular, not only protect their forest but also advocate among their neighbors for forest conservation and the reduction of agrochemicals to protect a larger area where bees can find flowers and maintain the organic certification of their honey. For people receiving cash from any of these sources in Calakmul or from forest concessions in MBR, clearing the forest has an opportunity cost that they can measure in dollars. In the midst of climate variability, people told me that relying on forest products is safer than on crops or even on cattle, which requires high investment in water for the animals. Bees can be affected by droughts or hurricanes, but the cost of supplemental feed (sugar) is relatively low, and government programs and strong leadership have made sugar available in cases of emergency. If there is a drought, people might lose their crops, but roads in the forest remain accessible, which allows people who rely on the sale of timber and nontimber forest products to extract for longer periods. These examples show how directly and indirectly, through discouraging cattle ranching, cash benefits from the forest support conservation.

\section{Distance, Population, and Conservation-Driving Adaptation Strategies}

Diversification, either through off-farm jobs or operating provision shops, is a conservation-driving strategy. This is because off-farm jobs and provision shops require no land and are labor intensive. When farmers choose either of these two activities, they have limited time left to allocate to other economic activities. Due to their strong traditions, people explained to me they still invest a fraction of their effort in growing their own corn. Otherwise people with jobs and shops substantially reduce their farming effort, and with it, they tend to let fallows grow and stop or decrease forest clearing. Adapting to climate variability through jobs and provision shops appeals to farmers because in general the revenues of these activities are greater than the revenues from agriculture, but more so when they are stressed by climate. The income farmers get from jobs and shops is mostly independent from climate events. Shop owners sell less or have to provide credit to clients when climate affects crops and people cannot afford to buy from the shop. Nonetheless, shop owners claimed they were better off with their shop than without it.

Socioeconomic factors also influence farmers' selection of jobs and shops to adapt. Distance to the center and the number of family members are particularly important. When you travel in Calakmul and MBR, you notice shops in every community, but the farther you go from the commercial center, the more common shops become. This is because families' reliance on the goods offered in community provision shops increases together with the costs of traveling to the commercial center. Time and money deter people from going to the market to get supplies. The local provision shops offer a variety of goods, which can also be bought on credit or in small portions that reduce the out-of-pocket expense. A captive market encourages the adoption of shops as an adaptation strategy as it has large expected profits.

Beyond its impact on the selection of diversification and saving adaptation strategies, the scholarship on land-use change has found that distance is a critical factor for deforestation (Nagendra et al. 2006, Roy Chowdhury 2006, Bray et al. 2008, Carr 2008). Proximity to commercial and administrative centers creates more opportunities for people to commercialize their agricultural products, send their children to school and network with farmers from different communities and governmental and nongovernmental organizations, which expand farmers' horizons beyond landintensive activities.

The number of family members is an important factor farmers consider when choosing their adaptation strategies. The model indicates that larger families have more hectares cleared. This is because the ability of small families to work the land is limited compared with large families given that agriculture is labor intensive. Jobs and shops are also labor intensive but demand less from families with few, young, or grown-up children. Hence, small families are more likely to choose conservation-driving adaptation strategies and clear fewer hectares of forest. Thus, the size of the family influences deforestation through its influence on the selection of adaptation strategies. Directly, population also influences deforestation because the need to produce food and hence to clear land is greater for larger families.

\section{Participation}

The effect of exclusion on the number of hectares farmers cut is not clearly connected with the selection of saving or diversification strategies. Yet, it is a critical factor explaining deforestation. The analysis of this paper and the literature indicate that participation in decision-making processes influences farmers' protection of natural resources (Agarwal 2001, Ribot 2004, Persha et al. 2011). In Calakmul and MBR, I found that farmers with no access to decision-making councils or to benefits derived from the decisions made in those councils consider themselves excluded. Excluded farmers are resentful and antagonistic toward any organization advocating for forest conservation and may clear more hectares than farmers who are not excluded. This is because, to meet forest conservation demands coming from the government, farmers have to work on land that has been cultivated for several years, instead of on land that has been recently cleared. Older clearings are hard to work due to the growth of weeds and loss of soil productivity, which leads to higher costs and smaller harvests that translate into welfare losses. Hence, farmers feel entitled to either receive compensation in exchange for their efforts and losses or to continue clearing the forest.

Farmers that participate in decision-making councils expressed that they value their participation in discussions about natural resources management because it gives them the opportunity to share their knowledge, advocate for their interests, and open opportunities for themselves. These farmers also tend to explain their receptiveness to conservation initiatives and development of economic activities with low land intensity as a result of their participation in decision making.

\section{CONCLUSIONS}

Unintended outcomes of climate adaptation strategies have been widely discussed, however, empirical exploration has been neglected. In this paper, I show that climate adaptation can increase or decrease forest loss depending on the type of adaptation strategy farmers implement. In Calakmul and MBR, farmers who choose to save through cattle ranching as an 
adaptation strategy increase their clearing of the forest. Deforestation can have negative consequences for farmers' welfare, as well as harm biodiversity and contribute to increased climate change. Thus, deforestation-driving adaptation strategies may be ineffective. However, farmers who choose diversification to adapt support forest conservation. This may lead to a virtuous circle in which livelihood improvement in the short term leads to enhanced social-ecological resilience in the longer term. The need for farmers to implement adaptation strategies thus represents great risk but also opportunities. A narrow focus on alleviating the impacts of climate on livelihoods without examining the ecological impacts of adaptation misses the broader interactions between people and ecosystems.

Responses to this article can be read online at: http://www.ecologyandsociety.org/issues/responses. php/6509

\section{Acknowledgments:}

Funding for this research was provided by Mexican National Council of Science and Technology (CONACyt), the National Science Foundation, University of Michigan, the Ostrom Workshop in Political Theory and Policy Analysis at Indiana University, and the Center for US-Mexican Studies at University of California San Diego. Thanks to Arun Agrawal, Maria Carmen Lemos, Ashwini Chhatre, Edward Parson, Ronald Inglehart, David Lopez Carr, Eduardo Brondizio, Alberto Diaz Cayeros, Forrest Fleischman, Catherine Benson, and Lynn Stephen for their insightful comments and to David Lutz for his help with the map.

\section{LITERATURE CITED}

Abramovitz, J., T. Banuri, P. Girot, B. Orlando, N. Schneider, E. Spanger-Siegfried, J. Switzer, and A. Hammill. 2002. Adapting to climate change: natural resources management and vulnerability reduction. World Conservation Union (IUCN), Gland, Switzerland; World Watch Institute, Washington, D.C., USA; International Institute for Sustainable Development (IISD), Geneva, Switzerland; Stockholm Environmental Institute, Stockholm, Sweden. [online] URL: http://search.iisd.org/ pdf/2002/envsec_cc bkgd_paper.pdf

Acopa, D., and E. Boege. 1997. The Maya forest in Campeche, Mexico: experiences in forest management at Calakmul. Pages 83-97 in R. B. Primack, D. Bray, H. Galleti, and I. Ponciano, editors. Timber, tourists, and temples: conservation and development in the Maya Forest of Belize, Guatemala, and Mexico. Island Press, Washington, D.C., USA.

Adger, W. N. 2005. Adapting to climate change: perspectives across scales. Global Environmental Change 15:75-76.

Adger, W. N., N. Arnell, and E. Tompkins. 2005. Successful adaptation to climate change across scales. Global Environmental Change 15:77-86.

Adger, W. N., P. M. Kelly, A. Winkels, L. Q. Huy, and C. Locke. 2002. Migration, remittances, livelihood trajectories, and social resilience. Ambio 31:358-366.
Agarwal, B. 2001. Participatory exclusions, community forestry, and gender: an analysis for South Asia and a conceptual framework. World Development 29:1623-1648.

Agrawal, A. 2001. Common property institutions and sustainable governance of resources. World Development 29:1649-1672.

Agrawal, A. 2005. Environmentality: technologies of government and the making of subjects. Duke University Press, Durham, North Carolina, USA.

Agrawal, A. 2008. The role of local institutions in adaptation to climate change. World Bank, Washington, D.C., USA.

Agrawal, A., and A. Chhatre. 2006. Explaining success on the commons: community forest governance in the Indian Himalaya. World Development 34:149-166.

Agrawal, A., and A. Chhatre. 2011. Strengthening causal inference through qualitative analysis of regression residuals: explaining forest governance in the Indian Himalaya. Environment and Planning A 43:328-346.

Agrawal, A., and N. Perrin. 2008. Climate adaptation, local institutions, and rural livelihoods. International Forestry Resources and Institutions (IFRI) working paper W081-6. IFRI, University of Michigan, Ann Arbor, Michigan, USA.

Agrawal, A., and G. Yadama. 1997. How do local institutions mediate market and population pressures on resources? Forest panchayats in Kumaon, India. Development and Change 28:435465 .

Alcantara-Ayala, I., and A. P. Dykes. 2010. Land use change in the tropics: causes, consequences and monitoring in Mexico. Singapore Journal of Tropical Geography 31:143-151.

Angelsen, A., and D. Kaimowitz. 2001. Agricultural technologies and tropical deforestation. CABI Publicaton in association with Center for International Forestry Research, Wallingford, Oxon, UK and New York, New York, USA.

Arreola, A., R. Delgadillo, A. López, and G. Gerardo. 2004. Diagnóstico de la situación del desarrollo en el municipio de Calakmul, Campeche. Proyecto Prosureste - GTZ/Comisión Nacional de Àreas Naturales Protegidas (CONANP), Mexico City, Mexico.

Barnett, J., and S. O’Neill. 2010. Maladaptation. Global Environmental Change - Human and Policy Dimensions 20:211213.

Barona, E., N. Ramankutty, G. Hyman, and O. T. Coomes. 2010. The role of pasture and soybean in deforestation of the Brazilian Amazon. Environmental Research Letters 5:1-9. http://dx.doi. org/10.1088/1748-9326/5/2/024002

Batterbury, S., and T. Forsyth. 1999. Fighting back: human adaptations in marginal environments. Environmental Science and Policy 41:6.

Bauer, D. J. 2003. Estimating multilevel linear models as structural equation models. Journal of Educational and Behavioral Statistics 28:135-167.

Bauer, D. J., K. J. Preacher, and K. M. Gil. 2006. Conceptualizing and testing random indirect effects and moderated mediation in 
multilevel models: new procedures and recommendations. Psychological Methods 11:142-163.

Bohle, H. G., T. E. Downing, and M. J. Watts. 1994. Climate change and social vulnerability: toward a sociology and geography of food insecurity. Global Environmental Change 4:3748 .

Bottazzi, P., and H. Dao. 2013. On the road through the Bolivian Amazon: a multi-level land governance analysis of deforestation. Land Use Policy 30:137-146.

Bray, D. B., E. Duran, V. H. Ramos, J. F. Mas, A. Velazques, R. B. McNab, D. Barry, and J. Radachowsky. 2008. Tropical deforestation, community forests, and protected areas in the Maya forest. Ecology and Society 13(2): 56. [online] URL: http://www. ecologyandsociety.org/vol13/iss2/art56/

Brondizio, E. S., and E. F. Moran. 2008. Human dimensions of climate change: the vulnerability of small farmers in the Amazon. Philosophical Transactions of the Royal Society B - Biological Sciences 363:1803-1809. doi: http://dx.doi.org/10.1098/ rstb.2007.0025http://dx.doi.org/10.1098/rstb.2007.0025

Brown, K. 2011. Sustainable adaptation: an oxymoron? Climate and Development 3:21-31. http://dx.doi.org/10.3763/cdev.2010.0062

Busch, C., and J. Geoghegan. 2010. Labor scarcity as an underlying cause of the increasing prevalence of deforestation due to cattle pasture development in the southern Yucatan region. Regional Environmental Change 10:191-203.

Calakmul, H. A. 2009. Plan municipal de desarrollo 2009-2012. Calakmul, Mexico.

Calakmul, H. A. 2012. Plan municipal de desarrollo 2012-2015. Calakmul, Mexico.

Carr, D. 2000. Un perfil socioeconómico y demográfico del Parque Nacional Sierra de Lacandón. Pages 93-106 in Facultad Latinoamericana de Ciencias Sociales (FLACSO), editor. Encuentro internacional de investigadores: nuevas perspectivas de desarrollo sostenible en Petén, Guatemala. FLACSO, Guatemala City, Guatemala.

Carr, D. L. 2008. Farm households and land use in a core conservation zone of the Maya Biosphere Reserve, Guatemala. Human Ecology 36:231-248.

Chapin, F. S. III, E. S. Zavaleta, V. T. Eviner, R. L. Naylor, P. M. Vitousek, H. L. Reynolds, D. U. Hooper, S. Lavorel, O. E. Sala, S. E. Hobbie, M. C. Mack, and S. Diaz. 2000. Consequences of changing biodiversity. Nature 405:234-242. http://dx.doi. org/10.1038/35012241

Cinner, J. E., C. Folke, T. Daw, and C. C. Hicks. 2011. Responding to change: using scenarios to understand how socioeconomic factors may influence amplifying or dampening exploitation feedbacks among Tanzanian fishers. Global Environmental Change - Human and Policy Dimensions 21:7-12.

Consejo Nacional de Àreas Protegidas (CONAP). 2001a. Base de datos sobre población tierras y medio ambiente en la Reserva de la Biósfera Maya, Guatemala. CONAP, Guatemala City, Guatemala.
Consejo Nacional de Àreas Protegidas (CONAP). 2001b. Plan maestro de la reserva de la biósfera Maya. CONAP, Petén, Guatemala. CONAP, Guatemala City, Guatemala.

Conservation International (CI). 2012. The biodiversity hotspots. Conservation International, Arlington, Virginia, USA. [online] URL: http://www.conservation.org/where/priority areas/hotspots/ north central america/Mesoamerica/Pages/default.aspx.

Dale, V. H. 1997. The relationship between land-use change and climate change. Ecological Applications 7:753-769.

Eakin, H. 2005. Institutional change, climate risk, and rural vulnerability: cases from Central Mexico. World Development 33:1923-1938.

Eriksen, S., and K. Brown. 2011. Sustainable adaptation to climate change. Climate and Development 3:3-6. http://dx.doi. org/10.3763/cdev.2010.0064

Faust, B. B. 2004. The end of the innocence in a modernizing Maya community: there is no more timber; let's sell the land! Pages 131-161 in B. B. Faust, E. N. Anderson, and J. G. Frazier, editors. Rights, resources, culture, and conservation in the land of the Maya. Praeger, Westport, Connecticut, USA.

Faust, B. B., E. N. Anderson, and J. G. Frazier. 2004. Rights, resources, culture, and conservation in the land of the Maya. Praeger, Westport, Connecticut, USA.

Fazey, I., N. Pettorelli, J. Kenter, D. Wagatora, and D. Schuett. 2011. Maladaptive trajectories of change in Makira, Solomon Islands. Global Environmental Change 21:1275-1289.

Foley, J. A., R. DeFries, G. P. Asner, C. Barford, G. Bonan, S. R. Carpenter, F. S. Chapin, M. T. Coe, G. C. Daily, H. K. Gibbs, J. H. Helkowski, T. Holloway, E. A. Howard, C. J. Kucharik, C. Monfreda, J. A. Patz, I. C. Prentice, N. Ramankutty, and P. K. Snyder. 2005. Global consequences of land use. Science 309:570 574.

Geist, H., and E. Lambin. 2001. What drives tropical deforestation? A meta analysis of proximate and underlying causes of deforestation based on subnational case study evidence. LUCC International Project Office, University of Louvain, Louvain-laNeuve, Belgium.

Geist, H. J., and E. F. Lambin. 2002. Proximate causes and underlying driving forces of tropical deforestation. Bioscience 52:143-150. http://dx.doi.org/10.1641/0006-3568(2002)052[0143: PCAUDF]2.0.CO;2

Gelman, A., and J. Hill. 2007. Data analysis using regression and multilevel/hierarchical models. Cambridge University Press, Cambridge, UK and New York, New York, USA.

Gibson, C., E. Ostrom, and M. A. McKean. 2000. Forest, people and governance: some initial theoretical lessons. In C. C. Gibson, M. A., McKean and E. Ostrom, editor. People and forest, communities institutions and governance. MIT Press, Cambridge, Massachussetts, USA.

Gómez, I., and E. Méndez. 2007. Association of forest communities of Petén, Guatemala. Context, accomplishments and challenges. Preferred Reporting Items for Systematic Reviews and 
Meta-Analyses (PRISMA), Center for International Forestry Research (CIFOR), Bogor Barat, Indonesia. [online] URL: http:// www.cifor.org/acm/download/pub/grassroot/Peten $\% 20$ guatemala_eng $\%$ 20All.pdf

Grandia, L. 2009. Raw hides: hegemony and cattle in Guatemala's northern lowlands. Geoforum 40:720-731.

Grandia, L. 2012. Enclosed: conservation, cattle, and commerce in among the Q'eqchi' Maya lowlanders. University of Washington Press, Seattle, Washington, USA.

Halstead, P., and J. O’Shea. 1989. Bad year economics: cultural responses to risk and uncertainty. Cambridge University Press, Cambridge, UK and New York, New York, USA. http://dx.doi. org/10.1017/CBO9780511521218

Herrero, M., P. K. Thornton, P. Gerber, and R. S. Reid. 2009. Livestock, livelihoods and the environment: understanding the trade-offs. Current Opinion in Environmental Sustainability 1:111120.

Hosonuma, N., M. Herold, V. de Sy, R. S. de Fries, M. Brockhaus, L. Verchot, A. Angelsen, and E. Romijn. 2012. An assessment of deforestation and forest degradation drivers in developing countries. Environmental Research Letters 7: 044009. http://dx. doi.org/10.1088/1748-9326/7/4/044009

Instituto Nacional de Ecologia (INE). 1999. Programa de manejo Reserva de la Biosfera de Calakmul. Instituto Nacional de Ecologia, Mexico City, Mexico.

Instituto Nacional de Sismología, Vulcanología, Meteorología e Hidrología (INSIVUMEH). 2008. Proyecto hidrometeorológico del Norte Petén. Departamento de Investigaciones y Servicios Hídricos, Guatemala.

Intergovernmental Panel on Climate Change (IPCC). 2007a. Climate change 2007: impacts, adaptation and vulnerability. Working Group II Contribution to the Intergovernmental Panel on Climate Change Fourth Assessment Report. IPCC, Geneva, Switzerland.

IPCC. 2007b. Climate Change 2007: synthesis report. contribution of working groups I, II and III to the Fourth Assessment Report of the Intergovernmental Panel on Climate Change. (Core Writing Team: R. K. Pachauri and A. Reisinger, editors..). IPCC, Geneva, Switzerland.

Keys, E., and R. Roy Chowdhury. 2006. Cash crops, smallholder decision-making and institutional interactions in a closing frontier: Calakmul, Campeche, Mexico. Journal of Latin American Geography 5(2): 75-90. [online] URL: http://muse.jhu. edu/login?auth=0\&type=summary\&url=/journals/ journal_of_latin_american_geography/v005/5.2keys.html

Klepeis, P., and B. L. Turner. 2001. Integrated land history and global change science: the example of the Southern Yucatan Peninsular Region project. Land Use Policy 18:27-39.

Lambin, E., B. L. Turner, H. J. Geist, S. B. Agbola, A. Angelsen, J. W. Bruce, O. T. Coomes, R. Dirzo, G. Fischer, C. Folke, P. S. George, K. Homewood, J. Imbernon, R. Leemans, X. B. Li, E. F. Moran, M. Mortimore, P. S. Ramakrishnan, J. F. Richards, H. Skanes, W. Steffen, G. D. Stone, U. Svedin, T. A. Veldkamp, C.
Vogel, and J. C. Xu. 2001. The causes of land-use and land-cover change: moving beyond the myths. Global Environmental Change $11: 261-269$.

Lambin, E. F., and P. Meyfroidt. 2011. Global land use change, economic globalization, and the looming land scarcity. Proceedings of the National Academy of Sciences of the United States of America 108:3465-3472. http://dx.doi.org/10.1073/ pnas. 1100480108

Lemos, M. C., and A. Agrawal. 2006. Environmental governance. Annual Review of Environment and Resources 31:297-325.

Locatelli, B., M. Brockhaus, A. Buck, and I. Thompson. 2010. Forests and adaptation to climate change: challenges and opportunities. International Union of Forest Research Organizations (IUFRO), Vienna, Austria.

MacKinnon, D., J. Krull, and C. Lockwood. 2000. Equivalence of the mediation, confounding and supression effect. Prevention Science 1:173-181.

Mexican National Water Commission (CNA). 2008. Proyecto de bases de datos climatológicos 1966-2008. Mexican National Water Comission (CNA), Subdirección General Técnica, Unidad del Servicio Meteorológico Nacional, Mexico City, Mexico.

Milian, B. 2008. Poverty, deforestation and land tenure institutions: the case of the communities living in Guatemala's Maya Biosphere Reserve. Dissertation, University of Massachusetts, Amherst, Massachusets, USA.

Nagendra, H., S. Pareeth, and R. Ghate. 2006. People within parks-forest villages, land-cover change and landscape fragmentation in the Tadoba Andhari Tiger Reserve, India. Applied Geography 26(2):96-112.

Nelson, D. R., W. N. Adger, and K. Brown. 2007. Adaptation to environmental change: contributions of a resilience framework. Annual Review of Environment and Resources 32:395-419.

Ostrom, E. 2009. A general framework for analyzing sustainability of social-ecological systems. Science 325:419-422.

Pérez-Salicrup, D. 2004. Forest types and their implications. Pages 63-80 in B. L. Turner, J. M. Geoghegan, and D. R. Foster, editors. Integrated land-change science and tropical deforestation in the southern Yucatán: final frontiers. Oxford University Press, Oxford, UK and New York, New York, USA.

Persha, L., A. Agrawal, and A. Chhatre. 2011. Social and ecological synergy: local rulemaking, forest livelihoods, and biodiversity conservation. Science 331:1606-1608.

Persha, L., H. Fischer, A. Chhatre, A. Agrawal, and C. Benson. 2010. Biodiversity conservation and livelihoods in humandominated landscapes: forest commons in South Asia. Biological Conservation 143:2918-2925.

Ponciano, I. 1997. Forest policy and protected areas in the Petén, Guatemala. Pages 99-110 in R. B. Primack, D. Bray, H. Galleti, and I. Ponciano, editors. Timber, tourists, and temples. conservation and development in the Maya Forest of Belize, Guatemala, and Mexico. Island Press, Washington, D.C., USA. 
Primack, R. B., D. Bray, H. Galleti, and I. Ponciano. 1997. Timber, tourists, and temples: conservation and development in the Maya Forest of Belize, Guatemala, and Mexico. Island Press, Washington, D.C., USA.

Pronatura Península de Yucatán (PPY) and The Nature Conservancy (TNC). 2006. Una visión para el futuro: cartografía de las selvas Maya, Zoque y Olmeca. PPY and TNC, San José, Costa Rica.

Radachowsky, J., V. H. Ramos, R. McNab, E. H. Baur, and N. Kazakov. 2012. Forest concessions in the Maya Biosphere Reserve, Guatemala: a decade later. Forest Ecology and Management 268:18-28.

Rao, M., S. Htun, T. Zaw, and T. Myint. 2010. Hunting, livelihoods and declining wildlife in the Hponkanrazi Wildlife Sanctuary, North Myanmar. Environmental Management 46:143153.

Raudenbush, S. W., and A. S. Bryk. 2002. Hierarchical linear models: applications and data analysis methods. Sage Publications, Thousand Oaks, California, USA.

Ribot, J. C. 2004. Waiting for democracy: the politics of choice in natural resource decentralization. World Resources Institute (WRI), Washington, D.C., USA. [online] URL: http://pdf.wri. org/wait for democracy.pdf

Roy Chowdhury, R. 2006. Landscape change in the Calakmul Biosphere Reserve, Mexico: Modeling the driving forces of smallholder deforestation in land parcels. Applied Geography 26:129-152.

Roy Chowdhury, R. 2010. Differentiation and concordance in smallholder land use strategies in southern Mexico's conservation frontier. Proceedings of the National Academy of Science USA 107:5780-5785. http://dx.doi.org/10.1073/pnas.0905892107

Rudel, T. K. 2006. Shrinking tropical forests, human agents of change, and conservation policy. Conservation Biology 20:1604 1609.

Rudel, T. K., R. de Fries, G. P. Asner, and W. F. Laurance. 2009. Changing drivers of deforestation and new opportunities for conservation. Conservation Biology 23:1396-1405.

Scarborough, V. L., and G. G. Gallopin. 1991. A water storage adaptation in the Maya lowlands. Science 251:658-662.

Schlager, E., and E. Ostrom. 1992. Property rights regimes and natural resources: a conceptual analysis. Land Economics 68:249262.

Schmook, B., C. Vance, P. Klepeis, and E. Keys. 2003. Características de los ejidos del sur de los estados de Campeche y Quintana Roo: resultados del proyecto SYPR. Quintana Roo, México.

Schmook, B., N. Vliet, C. Radel, M. Manzón-Che, and S. McCandless. 2013. Persistence of swidden cultivation in the face of globalization: a case study from communities in Calakmul, Mexico. Human Ecology 41:93-107.

Schwartz, N. B. 1987. Colonization of northern Guatemala: the Petén. Journal of Anthropological Research 43:163-183.
Schwartz, N. B. 1990. Forest society: a social history of Petén, Guatemala. University of Pennsylvania Press, Philadelphia, Pennsylvania, USA.

Soini, E. 2005. Land use change patterns and livelihood dynamics on the slopes of Mt. Kilimanjaro, Tanzania. Agricultural Systems 85:306-323.

Sunderland, T. C. H., B. Powell, A. Ickowitz, S. Foli, M. PinedoVasquez, R. Nasi, and C. Padoch. 2013. Food security and nutrition. Center for International Forestry Research (CIFOR), Bogor, Indonesia.

Turner, B. L. 2010a. Land change in the southern Yucatan: case studies in land change science. Regional Environmental Change 10:169-174.

Turner, B. L. 2010b. Sustainability and forest transitions in the southern Yucatan: The land architecture approach. Land Use Policy 27:170-179.

Turner, B. L., J. M. Geoghegan, and D. R. Foster. 2004. Integrated land-change science and tropical deforestation in the southern Yucatán: final frontiers. Oxford University Press, Oxford, UK and New York, New York, USA.

Turner, B. L. II, E. F. Lambin, and A. Reenberg. 2007. The emergence of land change science for global environmental change and sustainability. Proceedings of the National Academy of Sciences of the United States of America 104:20666-20671. http://dx.doi.org/10.1073/pnas.0704119104

United Nations Development Programme (UNDP). 2012. Management and conservation organization (OMYC), Uaxactún. New York, New York, USA.

van de Giesen, N., J. Liebe, and G. Jung. 2010. Adapting to climate change in the Volta Basin, West Africa. Current Science 98:10331037.

West, B. T., K. B. Welch, A. T. Galecki, and I. NetLibrary. 2007. Linear mixed models: a practical guide using statistical software. Chapman and Hall/CRC, Boca Raton, Florida, USA.

Woodroffe, R., S. J. Thirgood, and A. Rabinowitz. 2005. People and wildlife: conflict or co-existence. Cambridge University Press, Cambridge, UK. http://dx.doi.org/10.1017/CBO9780511614774

Ybarra, M., O. Obando-Samos, L. Grandia, and N. B. Schwartz. 2012. Tierra, migración y vida en Petén 1999-2009. Instituto de Estudios Agrarios y Rurales (IDEAR), Guatemala City, Guatemala. 